This is a self-archived version of an original article. This version may differ from the original in pagination and typographic details.

Author(s): Hyvönen, Ari-Elmeri

Title: Labor as Action : the Human Condition in the Anthropocene

Year: 2020

Version: Accepted version (Final draft)

Copyright: (c) Brill, 2020

Rights: In Copyright

Rights url: http://rightsstatements.org/page//nC/1.0/?language=en

Please cite the original version:

Hyvönen, A.-E. (2020). Labor as Action : the Human Condition in the Anthropocene. Research in Phenomenology, 50(2), 240-260. https://doi.org/10.1163/15691640-12341449 


\section{Labor as Action: The Human Condition in the Anthropocene}

Ari-Elmeri Hyvönen, DSocSci

University of Jyväskylä, Finland

DRAFT VERSION (Final draft)

Published version citation:

Hyvönen, Ari-Elmeri (2020), "Labor as Action: The Human Condition in the Anthropocene".

Research in Phenomenology 50 (2), pp. 240-260.

Available at: https://brill.com/view/journals/rip/50/2/article-p240_6.xml

DOI: https://doi.org/10.1163/15691640-12341449 


\title{
Labor as Action: The Human Condition in the Anthropocene
}

\begin{abstract}
The Anthropocene has become an umbrella term for the disastrous transgression of ecological safety boundaries by human societies. The impact of this new reality is yet to be fully registered by political theorists. In an attempt to recalibrate the categories of political thought, this article brings Hannah Arendt's framework of The Human Condition (labor, work, action) into to the gravitational pull of the Anthropocene and current knowledge about the Earth System. It elaborates the historical emergence of our capacity to 'act in the mode of laboring' during fossil-fueled capitalist modernity, a form of agency relating to our collectively organized laboring processes reminiscent of the capacity of modern sciences to 'act into nature' discussed by Arendt. I argue that once read from an energy/ecology-centric perspective, The Human Condition can help us make sense of the Anthropocene predicament, and rethink the modes of collectively organizing the activities of labor, work, and action.
\end{abstract}

Keywords. Arendt, Earth, Anthropocene, climate change, labor, agency

\section{INTRODUCTION - WHAT ON EARTH IS HAPPENING?}

The ecological catastrophe we currently face places humankind in an unprecedented situation. By overshooting several planetary safety boundaries we, as a species, have altered the climate and other fundamental systems, flows, processes, and chemical cycles of the planet, bringing life on Earth to a critical threshold. The loss of stability in the Earth System is expected to be detrimental, deleterious "or potentially even disastrous" for both humans and most other species. ${ }^{1}$ It has been suggested that we have

\footnotetext{
${ }^{1}$ Johan Rockström et al., “A Safe Operating Space for Humanity,” Nature 461, no. 7263 (2009); R. Warren et al., “The Projected Effect on Insects, Vertebrates, and Plants of Limiting Global Warming to $1.5^{\circ} \mathrm{C}$ Rather than $2^{\circ} \mathrm{C}$," Science 360 , no. 6390 (2018); “'Media Release: Nature’s Dangerous Decline 'Unprecedented’; Species Extinction Rates 'Accelerating’ | IPBES,” accessed September 30, 2019, https://www.ipbes.net/news/Media-Release-Global-Assessment.
} 
entered an epoch defined by humankind as a geological agent - the Anthropocene ${ }^{2}$. Acknowledging our capability to change "the most basic physical processes of the Earth"3 ought to be shocking. The Anthropocene, as one commentator has it, is about "experiencing dynamic (and mostly damaging) change". ${ }^{4}$ No society before ours, Bruno Latour notes, "has had to grapple with the reactions of the earth system to the actions of eight or nine billion humans". Whether sufficient actions are taken or not, unimaginably colossal changes are ahead. Rising sea levels and the potential loss of habitable areas threaten the known cartography of the globe. Extreme weather, critical loss of biodiversity, endangered food security, the increasing frequency and severity of epidemics and conflicts, and the related rise in the number of refugees place immense pressures on socio-political institutions. ${ }^{6}$ Due to unpredictable tipping points, causing self-reinforcing process of abrupt change in climate, the currently agreed-upon obligations are insufficient for safely ruling out the "Hothouse Earth" scenario of runaway warming. ${ }^{7}$ Effective mitigation, in turn, requires making societies carbon negative in the upcoming decades, and radically adjusting land use and food production practices. Increasing evidence suggests that this cannot be done

\footnotetext{
${ }^{2}$ It is still undecided whether humans leave enough stratigraphic markers to warrant a new epoch in strictly geological terms, or when the Anthropocene emerged (the invention of fire, great fauna extinctions, the birth of agriculture, Watt's patent for the steam engine, or the era of Great Acceleration and first radioactive elements). The notion, in any case, serves as an umbrella term for the different faces the ecological catastrophe. See T Toivanen et al., "The Many Anthropocenes: A Transdisciplinary Challenge for the Anthropocene Research,” The Anthropocene Review 4, no. 3 (2017).

${ }^{3}$ Naomi Oreskes, “The Scientific Consensus on Climate Change: How Do We Know We're Not Wrong?,” in Climate Change: What It Means for You, Your Children, and Your Grandchildren, ed. Joseph DiMento and Pamela Doughman (Cambridge, MA: MIT Press, 2007), 93.

${ }^{4}$ Deborah Bird Rose, “Anthropocene Noir,” Arena Journal 41/42 (2013).

${ }^{5}$ Bruno Latour, Down to Earth: Politics in the New Climatic Regime (Cambridge: Polity, 2018), 44.

6 Intergovernmental Panel on Climate Change, “Climate Change 2014 Synthesis Report Summary for Policymakers,” (2014).

7 Will Steffen et al., "Trajectories of the Earth System in the Anthropocene," Proceedings of the National Academy of Sciences 115 , no. 33 (August 14, 2018): 8252-59; Barry Gills and Jamie Morgan, “Global Climate Emergency: After COP24, Climate
} Science, Urgency, and the Threat to Humanity," Globalizations Online First, September 24, 2019 (2019), 3. 
without abandoning one of the cornerstones of modern policymaking, economic growth as a goal. ${ }^{8}$ Thus, lest we wish to risk the entire civilization as we know it, a radical reorganization of socio-economic infrastructure is required.

In order to make sense of the Anthropocene and the urgent demands it poses for political thought, the current essay turns to Hannah Arendt's reflections on the human condition. Arendt's conceptualization of the three main activities of the active life - labor, work, and action - are indispensable for understanding how the Anthropocene has come about, and how we might be able to organize our collective existence differently. Her thought, furthermore, contains important insights for thinking about unprecedented and life-threatening situations without succumbing to the twin "articles of superstition": heedless optimism or reckless pessimism. ${ }^{9}$ For a contemporary reader attuned to the threats and horrors of anthropogenic climate change, the second paragraph in the Preface of The Origins of Totalitarianism, for example, feels uncannily familiar, a prelude to our predicament.

"Never has our future been more unpredictable, never have we depended so much on political forces that cannot be trusted to follow the rules of common sense and self-interest - forces that look like sheer insanity, if judged by the standards of other centuries. It is as though mankind had divided itself between those who believe in human omnipotence $[\ldots]$ and those for whom powerlessness has become the major experience of their lives. On the level of historical insight and political thought there prevails an ill-defined, general agreement that the essential structure of all civilizations is at the breaking point" ${ }^{\prime 10}$

\footnotetext{
${ }^{8}$ Jason Hickel and Giorgos Kallis, “Is Green Growth Possible?," New Political Economy (Online First, April 17, 2019).

${ }^{9}$ Hannah Arendt, The Origins of Totalitarianism, 1st edition (New York: Harcourt Brace, 1951), vii.

${ }^{10}$ Hannah Arendt, The Origins of Totalitarianism, vii.
} 
Today, too, the future is exceedingly unpredictable, albeit partly due to forces beyond human control, such as surprising feedback loops in the climate system. Additionally, the political forces prevailing in Australia, the United States, Brazil, and elsewhere - judged against the scientific consensus - indeed look like "sheer insanity" that cannot be trusted to follow the path of human self-interest. There are some who, seemingly believing in human omnipotence, construe the Anthropocene as a promise of us finally becoming the true masters of the Earth via geoengineering; others - such as small island states facing the prospect of disappearing from the surface of the Earth ${ }^{11}$ - are forced to suffer their ultimate powerlessness.

Despite her strange contemporaneity ${ }^{12}$, Arendt is rarely mentioned in the Anthropocene literature, except when listed alongside other 'unhelpful' upholders of modernist dualisms (e.g. nature/society, public/private). ${ }^{13}$ Donna Haraway's Staying with the Trouble lists Arendt as an ally, but her presence in the book is evanescent. ${ }^{14}$ Even Dipesh Chakrabarty's essay "The Human Condition in the Anthropocene" only passingly engages with her thought. ${ }^{15}$ In Arendt scholarship, ecological questions have received increasing attention, but these interpretations have orbited around questions of human-nature relations in general, and the links between sustainability and Arendt's 'world-centric' critique of consumerism. ${ }^{16}$

\footnotetext{
${ }^{11}$ Milla Vaha, “Drowning under: Small Island States and the Right to Exist,” Journal of International Political Theory 11:2 (2015).

${ }^{12}$ Charles Barbour and Ari-Elmeri Hyvönen, "In the Present Tense: Contemporary Engagements with Hannah Arendt," Philosophy Today 62, no. 2 (2018).

${ }^{13}$ E.g. William E. Connolly, Climate Machines, Fascist Drives, and Truth (Durham: Duke University Press, 2019), 3-5, 42.

${ }^{14}$ Donna J. Haraway, Staying with the Trouble: Making Kin in the Chthulucene (Durham: Duke University Press, 2016$), 5$.

${ }_{15}$ Dipesh Chakrabarty, "The Human Condition in the Anthropocene. The Tanner Lectures in Human Values.” (Yale University, February 18-19, 2015), 151. Available at https://tannerlectures.utah.edu/Chakrabarty\%20manuscript.pdf. ${ }^{16}$ Paul Ott, "World and Earth: Hannah Arendt and the Human Relationship to Nature," Ethics, Place \& Environment 12, no. 1 (2009); Bronislaw Szerszynski, “Technology, Performance and Life Itself: Hannah Arendt and the Fate of Nature,” The Sociological Review 51, no. 2/supp (2003); Paul Voice, "Consuming the World: Hannah Arendt on Politics and the Environment," Journal of International Political Theory 9, no. 2 (2013); Finn Bowring, “Arendt after Marx: Rethinking the
} 
Few have explored the consequences of bringing Arendt's thought directly into the gravitational pull of the Anthropocene. The only full-length article to do so thus far is Benjamin Lewis Robinson's paper on the temporality of thought in the present era, accompanied by short (and insightful) essays by Lucy Benjamin on the role of the Earth in judging, and John Macready on the fragility of the human condition. $^{17}$

In this article, I rethink, reorganize, and reconceptualize Arendt's basic categories of vita activa within the gravitational field of the Anthropocene, thereby highlighting aspects of The Human Condition that have been previously deemed marginal - such as questions relating to energy and metabolic cycles. I treat the Anthropocene as an event in the Arendtian sense - a new and challenging experience that brings to light its own history and forces us to critically reassess our pre-given categories. ${ }^{18}$ Although the Anthropocene is a gradual process rather than a clearly demarcated singular event, it is meaningful, I argue, to treat it as such from the perspective of political understanding. As a concept, it names a relatively recent experience; as a crisis it demands a response in the present. The Anthropocene also clearly opens up a new horizon towards the histories of modern technoscience and capitalism, like a blazing fire illuminating its own past - at least until we cannot see anything anymore because of the smoke and ashes. It discloses relationships between stable democratic societies, economic growth, and the use of high EROEI (energy returned on

Dualism of Nature and World," Rethinking Marxism 26, no. 2 (April 3, 2014); Laura Ephraim, Who Speaks for Nature? On the Politics of Science (Philadelphia: University of Pennsylvania Press, 2018).

${ }^{17}$ Benjamin Lewis Robinson, "Between Future and Past: An Exercise in Political Ecology," Hannah Arendt.Net 9 , no. 1

(2018); Lucy Benjamin, “Upon Which Notion of the Earth Do Our Judgments Build Worlds?,” Syndicate (2019), https://syndicate.network/symposia/philosophy/a-democratic-theory-of-judgment/; John Macready, "Everything is Fragile: Reading Arendt in the Anthropocene". The Hannah Arendt Center.

18 Arendt, The Modern Challenge to Tradition: Fragmente Eines Buchs (Göttingen: Wallstein, 2018), 137, 141-142, 164; Arendt, Thinking without a Banister. Essays in Understanding II, 1953-1975 (New York: Schocken Books, 2018), 328-329. 
energy invested) fuels by extractive capitalism - relationships we might have continued to ignore if it were not for the instability created by the unforeseen atmospheric-biospheric impacts of these fuels.

As Chakrabarty has argued, all political thought "will have to register this profound change in the human condition" (he writes "progressive" thought, but I think this should apply to any conservative thought worth its salt, too). ${ }^{19}$ Unfortunately, the situation prevailing in policy-making - that "we are not yet acting as if we are facing an urgent and life-threatening Emergency"20 - also applies to political theorists, most of whom continue to write as though the ecological and energy-related ramifications of socio-political developments did not exist. Most political theorists and other scholars are still rather comfortably seated in what Arendt called "the ivory tower of common sense" ${ }^{21}$ - an ivory tower, in our case, where energy questions, catastrophic weather events, and diminishing biota remain in the margins. Thinking through the Anthropocene requires not explaining away the shock of the event, continuing our analyses as though nothing has happened. The Anthropocene ought to leave its mark on any given topic in political theory.

The process of understanding, Arendt reminds us, begins with an "unpremeditated, attentive facing up to, and resisting of, reality". ${ }^{22}$ For these purposes, scientific knowledge is indispensable, but not enough. "We already know enough to ask the difficult questions", as Geoff Mann and Joel Wainwright rightfully note. ${ }^{23}$ In this essay, I seek to advance our ability to theoretically reconcile with the world as it has been given to us. I join other scholars seeking both to understand the Anthropocene as a political phenomenon

\footnotetext{
${ }^{19}$ Dipesh Chakrabarty, "Postcolonial Studies and the Challenge of Climate Change," New Literary History 43, no.1 (2012), 15.

${ }^{20}$ Gills and Morgan, "Global Climate Emergency", 1.

21 Arendt, Essays in Understanding 1930-1954: Formation, Exile, and Totalitarianism (New York: Schocken Books, 1994$), 194$.

22 Arendt, The Origins of Totalitarianism, vii-viii; Arendt, Modern Challenge to Tradition, 139.

${ }^{23}$ Joel Wainwright and Geoff Mann, Climate Leviathan: A Political Theory of Our Planetary Future (London: Verso, 2018$), 77$.
} 
and to 'geologize' social and political thought. ${ }^{24}$ It is hardly possible to keep on pretending that radical changes in the Earth System, the "the quintessence of the human condition" ${ }^{25}$, can leave the said condition untouched. Our given categories and concepts - including the Arendtian ones - will need to be rethought. What I propose, is, as Arendt herself so eloquently put it, "a reconsideration of the human condition from the vantage point of our newest experiences and our most recent fears". ${ }^{26}$ Only this way can the event of the Anthropocene shed its light on the history of the present world.

Thinking, as Arendt famously insisted, "what we are doing", leads me to contend that our geological agency can be illuminated by considering the collective organization of labor processes in fossil-based extractive capitalism as a form of action. Taking heed of the Anthropocene theoretically, then, impacts especially our understanding of labor, but its repercussions for the meaningfulness of political action are also devastating. If Arendt's original idea was to set natality and earthly immortality, in contrast to mortality, at the center of political thought, today the two are fatefully intertwined. Because of processes we as natal beings have released, our existence is increasingly tinted by a sense of collective beingtowards-death. Under such conditions, avoiding the conclusions reached by the prophets of doom seems difficult. It is against doomism, however, that I push in my conclusions. If we can see the Anthropocene as something more than 'another crisis', we are well capable of assuming responsibility for biodiversity on the planet, taking care of the Earth, and organizing our laboring processes in a different manner.

\section{LABOR, WORK, AND ACTION IN THE ANTHROPOCENE}

\section{Mephistopheles (bei Seite).}

\footnotetext{
24 Toivanen et al., “The Many Anthropocenes”, 193; Nigel Clark and Yasmin Gunaratnam, "Earthing the Anthropos? From 'Socializing the Anthropocene' to Geologizing the Social,’ European Journal of Social Theory 20, no. 1 (2017): 146-163.

25 Arendt, The Human Condition (Chicago: Chicago University Press, 1998), 2, 7.

26 Arendt, The Human Condition, 5.
} 
Die Elemente sind mit uns verschworen,

Und auf Vernichtung läuft's hinaus.

Goethe, Faust II, 11544-50

In this section, I sketch a new constellation that emerges when the three fundamental human activities of the vita activa enter the gravitational pull of the Anthropocene. What happens to our understanding of labor, work, and action when we properly take into account the fact of human geological agency? Can Arendt's concepts help us illuminate this agency? My inquiry can be seen as a continuation of the work Arendt herself was engaged in, when in The Human Condition and the essays written in the 1950s and early 1960s she traced the historical changes in the mutual relationships of the basic human capabilities. ${ }^{27}$ Before we can embark on that endeavor, however, it is necessary to take a moment to clarify what Arendt means by these activities. Although my interpretation of the activities is not unique, it is one that still faces resilient opposition from the remnants of once prevalent "territorial" reading of The Human Condition. $^{28}$

One of the most tenacious arguments against Arendt is that she considers one member of her triumvirate of fundamental activities, namely labor, as an unfortunate part of the human condition. When Arendt writes about the Greek attempts to "eliminate labor from the conditions of human life" or maps the history of its rise from the "lowest, most despised position to the highest rank" "29, it is sometimes assumed that she wholeheartedly supported the Greeks and considered the lowest rank as the natural position of laboring activity. This is a misreading. In fact, Arendt identifies with the laboring activity a certain type of elementary joy, a "sheer bliss of life as a whole", and describes the effortless life of the rich or the

\footnotetext{
${ }^{27}$ See e.g. Hannah Arendt, Between Past and Future: Eight Exercises in Political Thought (London: Penguin, 2006), 62.

28 Patchen Markell, “Arendt's Work: On the Architecture of 'The Human Condition," College Literature 38 (1) (2011): 15-44.

${ }^{29}$ Hannah Arendt, The Human Condition, 101, 119.
} 
slavemaster as "lifeless", vicarious, lacking vitality. ${ }^{30}$ Labor is not something she wishes to rid us of - it is its relationships to the other activities that matters. And although I will emphasize the centrality of labor for the eco-social catastrophe, my complaints are limited - in a fashion I think Arendt would find agreeable - to the collective organization of labor/consumption processes under capitalism.

On the most fundamental level labor, for Arendt, corresponds to biological life - to the necessities of our subsistence. Borrowing Marx's characterization of labor as the human "metabolism with nature", Arendt understands the activity in cyclical terms. Once produced, the fruits of labor are immediately consumed and "return into the natural processes which yielded them". 31 This cyclicality distinguishes labor from work. The latter involves making and using instruments in order to erect a human world. Unlike labor, work has a definite beginning and a definite end. The products of work are designed to stand the test of time, and because of this their material must be removed from the cycles of nature. The tree must be killed for wood, and the extraction of raw materials (ores, stone, marble) requires "interrupting one of nature's slower processes". Work, thus, creates a chasm between us and nature. We build a world by exercising violence against nature. It is only from the vantage point of that world that we can look at nature from an 'objective' perspective and imagine ourselves as its 'master'. ${ }^{32}$ The emphasis here is on 'imagine', because the cultural world and 'nature' are always intertwined, culture being "always cultivated nature - nature being tended and being taken care of by one of nature's products called man. If nature is dead culture will die too, together with all the artifacts of our civilization". ${ }^{33}$

\footnotetext{
30 Arendt, The Human Condition, 106-109, 119-121.

${ }^{31}$ Arendt, The Human Condition, 7, 96.

32 Arendt, The Human Condition, 137-139.

${ }_{33}$ Mary McCarthy and Hannah Arendt, Between Friends: The Correspondence of Hannah Arendt and Mary McCarthy 1949-1975

(New York: Harcourt, Brace, 1995), 293 (May 28, 1971); Arendt, The Human Condition, 97-100.
} 
In contrast to both labor's cyclicality and the segmented linearity of work, action - the third basic activity - involves releasing irreversible processes that have no predictable ends, although they "may have a definite beginning". The may will play a role in my argument later on, but at this point it suffices to note that on a general level beginning and acting are almost synonymous for Arendt. Political action is the arena where human beings are capable of initiating something new, responding to the deeds of others, and by doing so revealing their unique identities. By the same token, it is the "field of experience" for freedom. ${ }^{34}$

Considering the three activities of the vita activa from the viewpoint of the Anthropocene, work appears as the most obvious culprit for the destabilization of the Earth System we now face. Action takes place between humans, whereas labor is cyclical. Neither, on the face of it, is capable of intervening with the Earth's physical processes. Work, on the other hand, is by definition violent towards nature. Simon Swift indeed suggests that "Arendt's defense of the 'violence' that man does to nature in building a cultural world seems particularly out of sorts with the consciousness of impending ecological catastrophe". ${ }^{35}$ Arendt's description of work, however, also implies a kind of balance - or at least a potential for a balance - that does not quite fit our concerns with fossil-fueled extractive capitalism or radioactive elements dispersed across the Earth. The 'violence' Arendt talks about is too general to name anything specific in relation to the Anthropocene. Even a hermit in the woods, as long as they build a cabin or make a fire, exercise such violence. On a closer look, in fact, work may well turn out to be a key in resisting our current crisis. The activities of labor and action, then, are more crucial for understanding our geological agency. But to get to that conclusion, we need to approach the question from a different angle.

The static image of the three activities does not get us far in the attempt to understand the Anthropocene, nor does it correspond to what Arendt is doing in The Human Condition. The book relates a historical

\footnotetext{
34 Arendt, The Human Condition, 143-144, 176-179; Arendt, Between Past and Future, 145.

35 Simon Swift, Hannah Arendt (New York: Routledge, 2008), 137.
} 
development in which not only the mutual hierarchy between the activities, but to a large extent the activities themselves have undergone major alterations. The latter aspect is often bypassed in criticisms of Arendt's idea of the modern "rise of the social", i.e. the birth of laboring society run by administration rather than politics proper. What many readers get out of Arendt's historical narrative is the lamentation that modern society, due to the rise of labor to the center of public concern, "excludes the possibility of action", substituting it with statistically predictable behavior. ${ }^{36}$ But to say that Arendt criticizes the rise of labor to the top of the hierarchy is to tell only one side of the story. The other side has to do with the changes undergone by the three activities as such. It is with the help of a detour through these alterations that the framework of the vita activa can be placed in contact with the Anthropocene.

Against the background of the 'standard reading' of Arendt, the following claim in the final pages of "The Modern Concept of History" appears startling. "[F]or the first time in our history", she argues, "the human capacity for action has begun to dominate all others — the capacity for wonder and thought in contemplation no less than the capacities of homo faber and the human animal laborans" ${ }^{37}$. How is this statement to be reconciled with her complaint about administration substituting for action? The key here is to note that the modern age threatens political action, or rather the worldly opportunities for its exercise. But in a more general sense, modernity has in fact accentuated our capacity for action in a very tragic way. This more general sense in which Arendt uses the word action has received relatively little attention in the secondary literature, and admittedly she is not always very explicit about it. Non-political forms of action, however, are the key for understanding our agency in the Anthropocene, so it is worth paying more attention to this strand in Arendt's thought.

\footnotetext{
${ }^{36}$ Hannah Arendt, The Human Condition, 40-45.

${ }^{37}$ Hannah Arendt, Between Past and Future, 62. The said 1958 essay forms the first half of "The Concept of History".
} 
A key trajectory of modernity, for Arendt, has been the gradual development of an ability of the sciences to "act into nature". The human capacity for beginning new processes has been channeled into nature, and we have become capable of releasing processes that would not have occurred without us. For Arendt, the science of her age had taken the step into looking at the world from an extra-earthly, Archimedean point, and importing "cosmic processes into nature even at the obvious risk of destroying her and, with her, man's mastership over her". It is no coincidence that the emergence of 'universal science' would coincide with the discovery of our ability to "destroy all organic life on earth". Indeed, the "fateful repudiation" of Earth and "the human condition as it has been given" cast their shadows over The Human Condition as a whole. ${ }^{38}$ This stage has been reached in three steps: first, the turn to experimentation in early modern sciences; second, the provoking of natural processes (e.g. electricity), and third, the creation - in nuclear physics - of 'universal', stellar processes on Earth. ${ }^{39}$ Contemporary calls for geoengineering our way out of the climate crisis (they only propose to solve the climate part of the crisis) appear as an addendum to the third step, treating the whole Earth as their laboratory.

In Arendt's writings of the 1950s, the atom bomb acted as a central symbol for the potential destruction sowed by human "conspiracy" with the forces of nature..$^{40}$ Especially in the manuscript of one of her stillborn book projects, Einfübrung in die Politik, Arendt treated the possibility of nuclear annihilation as a unique threat not only for life, but for politics too. The prevalent sentiment of the age was, she argues, the skepticism regarding the compatibility of politics and the preservation of life under modern conditions. The fear of destruction led to a justified hope that we can get rid of politics before it is too

\footnotetext{
38 Arendt, The Human Condition, 2-3, 262, 268-269. Obviously, Arendt is not a science skeptic. It is the same "universal science" that today tells us that we are indeed very close to disturbing the natural processes of Earth to a point of no return. See also Roger Berkowitz, "The Human Condition Today: The Challenge of Science”. Arendt Studies, vol.2 (2018).

39 Arendt, The Human Condition, 230-233, 323-324; Arendt, Between Past and Future, 58.

40 Arendt, Essays in Understanding, 419.
} 
late. ${ }^{41}$ Today, many can certainly sympathize with such reaction, and entertain utopian hopes for a global state of sovereign exception, putting all politics on a hiatus until the existential crisis we face is solved.

The idea of sciences "acting into nature" seems to bring us back to the activity of work, because science is intimately related to fabrication. In fact, Arendt uses the expression "acting in the mode of making" to describe the agency of modern sciences. Science operates in the sphere of cognition (as opposed to thinking), which Arendt understands as a mental equivalent of work and its means-ends reasoning. ${ }^{42}$ This narrative, however, offers too narrow an analytical prism for a proper understanding of our predicament. Both nuclear destruction and scientific acting into nature leave something essential out of the picture and cannot directly be applied to the Anthropocene. The threat posed especially by nuclear destruction suggests too 'active' an image. And although modern science and technology - especially energy technology - play an important role in humankind becoming a geophysical force, they alone cannot explain the process. They might well be the engine, but not the driver, of this vehicle.

Our current understanding of the looming planetary catastrophe requires a way to account for the more mundane activities that are nevertheless capable of acting as triggers for the feedback processes in the Earth System. Doing so will also challenge Arendt's timing of the emergence of our capacity to act into nature. Not the $20^{\text {th }}$ century and the splitting of the atom, but the developments beginning in the $1450 \mathrm{~s}$ and culminating in the Second Industrial Revolution and the rise of carbon-fueled, extractive, consumer capitalism mark the beginning of human capacity to release uncontrollable natural processes. Although Arendt acknowledges the scale and devastating consequences of human agency in nature, she does not quite phrase this (nor could she have) in terms of the human animal conspiring with slow geological processes (carbons) so as to unwittingly effect a radical change in the Earth System as a whole. While she was perceptive to the world-threatening consequences of mundane activities, at her time it was hardly

\footnotetext{
${ }^{41}$ Hannah Arendt, The Promise of Politics (New York: Schocken Books, 2005), 97, 109.

42 Arendt, The Human Condition, 170-171, 238.
} 
imaginable that such activities could be thought as seriously threatening the core of the human condition as such. Although all of our activities are implicated in some way, it is the mundane activity of laboring and its societal organization, I submit, that has to be seen as the main culprit for the Anthropocene. What I want to argue here is that considered from the viewpoint of our most recent experiences (the Anthropocene) our way of metabolizing with nature has transformed into a form of agency. From the standpoint of Arendt's concepts, this means that labor has taken on more and more features that have been classically associated with action. From the viewpoint of the Anthropocene, labor is action.

One of the reasons why we need to look beyond the activity of work is that its capacity to develop modern technology backfires, as it were, on itself, rendering work almost meaningless in the modern world - a mere servant of the laboring and consuming process. The invention of the steam engine, according to Arendt, was still a matter of "imitation of natural processes and the use of natural forces for human purposes", whereas the harnessing of electricity implied a channeling of natural forces into the human world, causing it to change its shape quite radically. Most significant of such changes has been the birth of automation, and a virtual elimination of work in favor of the continuous process of laboring, and of use in favor of consumption. ${ }^{43}$ Displaying an openness to the kind of 'natural history of the social' approaches that are fashionable today, Arendt approvingly cites R.H. Barrow's thesis that early industrial technology might have emerged already in Rome if it was only a matter of human inventiveness. What made the difference at this stage was the use of coal to power the steam engines. ${ }^{44}$ Energy and fuel sources, then, play a decisive role in the modern transformation. Watt's patent for the first steam engine also resonates in an interesting manner with Arendt's analysis of labor under modernity and the idea of the steam engine as imitation of natural processes. The engine's wheel is a form of "continuous circular

\footnotetext{
43 Arendt, The Human Condition, 124-125, 148-149.

${ }^{44}$ Arendt, The Human Condition, 148.
} 
motion" ${ }^{45}$ which, under given social conditions, begins to feed a linear process of growth. This is exactly what happened to labor, too, under modernity in Arendt's telling.

The decisive event here is the expropriation of peasant property after Reformation, which exposed the underprivileged classes to the exigencies of life, creating both the original accumulation of wealth and capital, and the reserve of wage-laborers fit for exploitation. Labor - both wage-labor and the gendered/racialized organization of unpaid labor - was one of the first domains of 'cheap nature' captured by nascent capitalism, to borrow Jason W. Moore's conceptualization. ${ }^{46}$ Under these conditions, laboring was 'liberated' from the cyclical temporality imposed on it by the reproduction of life in the private and transformed "into swiftly progressing development", an "unheard-of process of growing wealth, growing property, growing acquisition". The ability of labor to produce a surplus beyond individual survival, once harnessed by a collectively organized life process on a big enough scale, let loose, Arendt famously argues, "an unnatural growth, so to speak, of the natural"47. Biological life plays a dual role in this development, providing both the physical basis of growth (through labor-power) and the metaphorical language (especially qua fertility) which became dominant for conceptualizing the seemingly automatic, accelerating growth of economic and social processes. ${ }^{48}$ Indeed, the image of growth as natural cuts so deep into the modern imagination that it is no wonder that contemporary pundits (even nondenialist ones) find it hard to let go of the idea of GDP growth even when presented evidence of the near-impossibility of absolute decoupling of growth and material throughput.

What we see more clearly now, in the light of the Anthropocene, is that the kind of self-propelling growth Arendt describes under modern conditions is not a result of social organization of labor alone, but

\footnotetext{
${ }^{45}$ Watt quoted in Malm, Fossil Capital: The Rise of Steam Power and the Roots of Global Warming (London: Verso, 2016$), 16$.

${ }^{46}$ Jason W. Moore, Capitalism in the Web of Life: Ecology and the Accumulation of Capital (New York: Verso, 2015), 62ff.

47 Arendt, The Human Condition, 47.

48 Arendt, The Human Condition, 45-47, 61, 66, 105-106, 116, 255.
} 
depends on the use of fossil fuels. Suddenly, most people have at their command the amounts of energy previously available only to those who owned dozens of slaves. Despite her emphasis on the role of coal in the industrial revolution, Arendt hardly understood how deeply the whole modern experience is dependent on carbons. In fact, as Andreas Malm has shown, even the social organization of labor in the early industrial production itself was made possible by the use of coal. ${ }^{49}$ Later, especially in the twentieth century, oil replaced coal as the defining fuel of modernity. Almost everything we consume is dependent on oil at some point of the production process. From plastics to pharmaceutical products, oil is in the things we consume. Non-oil-based products need to be transported. And the growth of population in the past hundred years was made possible by fossil fuels in agricultural machinery and the use of natural gas for pesticides and as a feedstock for fertilizers. Modern experience is the experience of oil. ${ }^{50}$ Even today, oil is irreplaceable for the functioning of our infrastructures. Alternative energy sources become meaningful 'solutions' only as affordances to a radically restructures societal existence. Once we take aboard this insight, Arendt's thinking gets us a long way in the articulation of the geological agency springing from our activities of laboring and consuming.

Arendt witnessed the birth of American consumer society first-hand. Writing to Karl Jaspers on Boxing Day in 1956, she notes: "Prosperity continues to prosper, picking up in pace all the time. Now everybody and his brother has not only two cars in the garage but three [...] I find it troubling, and I can hardly imagine how it can be for the good. But perhaps those are prejudices on my part and a lack of understanding of modern economics". 51 Arendt may or may not have lacked understanding regarding the imperatives of increased consumption for making of the post-war economic order. But looking back on her statement from our present-day perspective, she can certainly be said to have been onto something

\footnotetext{
49 Andreas Malm, Fossil Capital, 11, passim.

50 Antti Salminen and Tere Vadén, Energy and Experience: An Essay in Nafthology (Chicago: MCM', 2015).

${ }^{51}$ Hannah Arendt and Karl Jaspers, Correspondence, 1926-1969. (London: Harcourt Brace, 1992), 306.
} 
with her skepticism of the ultimate outcomes of accelerating growth and consumer abundance. Ever more so, the choice of example is very fitting. ${ }^{52}$ As Timothy Mitchell has shown, the automobile industry played a major role in the creation of "carbon-heavy middle-class American life". ${ }^{3}$ While critiques of consumerism abound, however, it is in many ways more useful to focus on the activity of labor as the primary term of the pair. All consumption depends on some or several form(s) of labor (or combination of labor and work): raising cattle, farming and deforestation, industrial production, fishing, mining, drilling, and so on. ${ }^{54}$ Consumer abundance is produced by labor. The pressures to extract resources, energy resources included, would be considerably altered if the dynamics of labor were different.

From this perspective, Arendt's historical narrative opens up to the concerns of ecohistory and ecological critique of capitalism, while also highlighting the limits of her vision. She was highly aware that the imperatives of labor need to be rethought: 'The precept 'he who does not work shall not eat' is as obsolete and open to challenge as the commandment 'be fertile and multiply'. Both were admirably suitable for an underpopulated, agricultural society". ${ }^{55}$ For society of affluence and ecological destruction, these precepts are a recipe for catastrophe. The details of this recipe have been explored among others by Rob Hengeveld and Marxist scholars elaborating the idea of "metabolic rift" mentioned in Das Kapital..$^{56}$ The idea, in short, is that earlier economies were largely tied to finite and immediate products

\footnotetext{
${ }^{52}$ Another fitting example is Arendt's emphasis on the airplane (a big producer of CO2) as a symbol of human alienation from the Earth. See Arendt, The Human Condition, 251.

53 Timothy Mitchell, Carbon Democracy: Political Power in the Age of Oil (London: Verso, 2013), 39-42.

${ }^{54}$ Lauri Lahikainen and Tero Toivanen, "Working the Biosphere: Towards an Environmental Philosophy of Work," Environmental Philosophy 16, no. 2 (2019).

${ }^{55}$ Hannah Arendt, Thinking without a Banister, 327.

${ }^{56}$ Rob Hengeveld, Wasted World: How Our Consumption Challenges the Planet (Chicago: University of Chicago Press, 2012); John Bellamy Foster, Richard York, and Brett Clark, The Ecological Rift: Capitalism's War on the Earth (New York: Monthly Review
} 
of photosynthesis, and thus to natural cyclicality. Modern farming, on the contrary, wears out the fertility of the soil. The fossil economy, in turn, uses the results of past photosynthesis, transformed by very slow geological processes before becoming ripe for extraction. This additional energy has been channeled to labor and consumption which produces so much waste (broadly understood) that it cannot be recycled, fed back into the cycles of the ecosystems, thereby disturbing the functioning of said systems. Arendt's reflections on 'waste economy ${ }^{57}$ and the transformation of human metabolism with nature are certainly in line with this critique, although she did not follow through on the ecological consequences.

Against todays' knowledge, though, it appears that we did not need - as Arendt still believed - "future techniques" (or nuclear weapons) to transform 'nature's household' ('ecology': oikos logos) to the same extent as previous technologies had challenged the "worldliness of the human artifice". ${ }^{8}$ The sheer volume of carbon-powered laboring and consuming (i.e. the economy, oikos nomos), and the number of people involved, sufficed. Rarely, furthermore, were Arendt's predictions quite as mistaken as when she suggested that the channeling of natural processes into the human world may threaten the world as a meaningful space for politics and culture, but will "reliably and limitlessly provide the species man-kind with the necessities of life". ${ }^{99}$ What she failed to account for, despite her cogent criticism of waste economy and acknowledgement of the intertwining qualities of world and nature, was the fact that these processes do not terminate in the human world - they return to the ecosystems. This waste, as we now know, can violate the functioning of the ecosystems to the extent where instead of reliably providing us with necessities, they start to crumble. The true irony of the development, fully detectable only now, is

Press, 2011); Kohei Saito, "Marx in the Anthropocene: Value, Metabolic Rift, and the Non-Cartesian Dualism," Zeitschrift Für Kritische Sorialtheorie Und Philosophie 4, no. 1-2 (2017): 276-295.

${ }^{57}$ E.g. Arendt, The Human Condition, 100, 124.

58 Arendt, The Human Condition, 150.

59 Arendt, The Human Condition, 152. 
that societies centered "around the one activity necessary to sustain life" to be closely linked to the threat faced by biological life on Earth.

Thus, labor is a key activity constituting our geological agency. And yet, we "lack adequate descriptive and normative theories" to fully understand this role. ${ }^{61}$ It is in the hope of contributing to the emergence of such sufficient theories that I next turn to Arendt's thoughts on action as an explication of labor as the root of our geological agency. While such a conclusion certainly goes beyond the scope of Arendt's own argumentation, it does not render her concepts completely antediluvian. Arendt's thought, on the contrary, is singularly well-equipped for the task due to the clear distinctions she draws between labor, work, and action. Exactly because she sets them analytically apart, in other words, Arendt is capable of illuminating the entwining of different activities in a way not to be expected from, say, Marxist analyses.

\section{INITIUM ESSET: LABOR-AS-ACTION}

"I suffered those deeds more than I acted them."

Sophocles, Oedipus at Colonus, 266

For Arendt, the human capacity for action is rooted in natality, the fact of "having been born". In Arendt scholarship, natality (like action) is usually treated in a celebratory manner. In laborers' society, it may be lamented, natality seems to turn into mere fertility, which signifies nothing, save perhaps the numerical growth of human populations. ${ }^{62}$ Natality in itself, in any case, is seen as a promise. The complaints, if there are any, are usually related to Arendt's tendency to limit the redemptive power of natality and action

\footnotetext{
${ }^{60}$ Arendt, The Human Condition, 46.

${ }^{61}$ Lahikainen and Toivanen, "Working the Biosphere."

62 Anne O’Byrne, Natality and Finitude (Bloomington: Indiana University Press, 2010), 91.
} 
to the public sphere. Rescuing work, labor, or the private sphere from Arendt's alleged depreciation, then, requires showing that natality - like Heraclitus's deities - is also present in non-public spheres of life. ${ }^{63}$ Arendt herself was well aware of this broader applicability. In the first pages of The Human Condition, she notes that in the sense of initiating something, "the element of action, and therefore of natality, is inherent in all buman activities". ${ }^{44}$ Following this thread in Arendt's work, I intend to show that collective organization of labor as a form of geological agency becomes, alongside scientific acting into nature, the dominant modality in which natality appears in the modern world.

All action carries with it the qualities of being unpredictable, irreversible, and having unbounded consequences. For these very reasons action and suffering are two sides of the same coin. Action is never sovereign, but instead the actor "never quite knows" what they are doing and "always becomes 'guilty" of unintended consequences. ${ }^{65}$ This is equally true for acting into the web of life as it is for acting into the web of human relations. In both cases, our deeds trigger a chain of reactions beyond our willful control. We become the victims of something we have started but cannot 'manage' - it is not as though the British cotton industry capitalists intended to initiate processes which ended up overshooting critical ecological thresholds. It is for these very reasons that labor in modernity needs to be understood as a type of action. Labor, as it was known before modernity, was circular. It by definition never produced any enduring results. Modern labor, on the other hand, releases processes whose strength is "never exhausted in single deed" but can go on without an end. ${ }^{66}$ These processes may also cross the threshold of becoming irreversible both in Arendt's phenomenological sense and in the technical sense (of the IPCC, for instance) of effecting a systemic change that cannot, within a meaningful timeframe (between hundreds

\footnotetext{
${ }^{63}$ E.g. Rosalyn Diprose and Ewa Plonowska Ziarek, Arendt, Natality and Biopolitics: Toward Democratic Plurality and Reproductive Justice (Edinburgh: Edinburgh University Press, 2018).

${ }^{64}$ Arendt, The Human Condition, 9. Emphasis mine.

65 Arendt, The Human Condition, 190-191, 233.

${ }^{66}$ Arendt, The Human Condition, 232-233.
} 
or thousands of years), be reversed to an initial stage, even if the drivers of the change cease. ${ }^{67}$ This potential irreversibility resonates with the tendency of action processes to become automatic, that is, beyond purposeful interference. ${ }^{68}$ This is indeed what is in risk of happening to the climate change.

Obviously, labor-as-action lacks many of the admired features of political action. Like the action of scientists, it can neither 'reveal' the acting person to their equals nor produce meaningful stories. ${ }^{69}$ It is not purposeful. It does not guarantee the experience of freedom and public happiness. Ours, then, is an agency without the plurality of unique beings. This is exactly what makes it dangerous. Labor is a mode of action, a geological force, but because it is not political action - it happens outside the framework of human relations - we are not equipped with the remedies that traditionally kept the unpredictability and unboundedness of action in check. We, by doing nothing more extraordinary than laboring and consuming, "have carried irreversibility and human unpredictability into the natural realm, where no remedy can be found to undo what has been done". Without these remedies the greatness of human power "begins to overpower and destroy not man himself but the conditions under which life was given to him". ${ }^{70}$ Because we are dealing with non-human causal forces, human interventions become increasingly difficult once the process has been set in motion. Glaciers can keep melting and releasing methane, acidification or deforestation can continue, past emissions will keep impacting the atmosphere even if we reached zero emissions today. Luckily, though, there are available counter-actions, too: the creation of carbon sinks or renewed land use practices can prevent the worst consequences effected by our past practices. The Greek emphasis on the importance of keeping within boundaries, to say the least, seems exceedingly pressing today.

\footnotetext{
${ }^{67}$ IPCC, “AR5 Synthesis Report: Climate Change 2014 (Annexes)”. https://www.ipcc.ch/report/ar5/syr/.

68 Arendt, The Human Condition, 151.

${ }^{69}$ Arendt, The Human Condition, 324.

70 Arendt, The Human Condition, 238.
} 
Unlike the action of scientists, labor-as-action is not an experience of the privileged few. ${ }^{71}$ For a long time it was barely an experience at all. But after the facts have come 'home to roost', all of us must learn to bear the weight of our capacity to act through labor. I mentioned before that, for Arendt, action may have a definite beginning. The Anthropocene story, I think, is one without a definite beginning. It is a "story with many beginnings and no end". ${ }^{72}$ Something was begun, but not in a specific location in time and space. There's little sense in speaking of a singular Anthropocene that has one definition and one origin ${ }^{73}$. All we know is that we are now suffering the consequences of the deeds of the fellow members of our species. Each individual is "confronted with, has to adjust to and tries to act into what all men together have done and suffered". ${ }^{74}$ We recognize ourselves, perhaps more empathetically than seventy years ago, from the reflections Arendt offered on the "factual responsibility" of mankind on the global scale which implies a "responsibility for all crimes committed by men". ${ }^{75}$ No one is an innocent bystander. Guilt is distributed unequally - fossil industries, extractive capital, merchants of doubt, and anti-climate-action politicians bearing the heaviest load. These "obscurantist elites", as Latour calls them, have taken the Eichmannian position of refusing to share the earth with the rest of the world. ${ }^{76}$ Responsibility, on the other hand, is something no one can escape. Consciously bearing this burden and turning it into meaningful action is the task we face now. Equally true, unfortunately, is the fact that there is always a tendency to escape responsibility, especially one combined with a sense of being punished for the crimes of others, into frustrated nationalism. ${ }^{77}$

\footnotetext{
${ }^{71}$ C.f. Arendt, The Human Condition, 324.

72 Arendt, The Modern Challenge to Tradition, 138.

${ }^{73}$ The history of the concept of Anthropocene has been presented countless times, and I will not reproduce it here. For an overview of the term's development and debates around it, see Toivanen et al., "The Many Anthropocenes."

${ }^{74}$ Arendt, The Modern Challenge to Tradition, 139.

${ }^{75}$ Arendt, Essays in Understanding, 131.

${ }^{76}$ Latour, Down to Earth, 21, 36; Hannah Arendt, Eichmann in Jerusalem: A Report on the Banality of Evil (New York: Penguin, 2006), 279.

${ }^{77}$ Hannah Arendt, The Origins of Totalitarianism, 436.
} 


\section{DEATH OF IMMORTALITY, BIRTH OF RESPONSIBLE GRATITUDE}

Our collectively organized labor process, I have argued, has taken the shape of action minus plurality, of initiating processes we can neither control nor release ourselves from. The implications of acting in the mode of laboring are disconcerting for contemporary social practices. But thinking through labor, work and action helps to envisage new possibilities. As a way of concluding, it is worth considering what this experience of the Anthropocene means for action in its worldly, political capacity. One of the key issues here is the question of immortality which, Arendt argued, had originally been the pivot of the vita activa. By the time Arendt was writing, the superfluity produced by modern society had already all but eroded the conditions for earthly immortality, save perhaps in a mode of "anonymous glory" ${ }^{78}$ These worries, ever more prevalent today, place us face to face with the limits of human courage, and hence of political action, which hinges on the existence of a posterity that understands and remembers the "mortal sacrifice" as a meaningful part of the "'enduring chronicle of mankind,' as Faulkner once put it". 79

Hans Jonas, Arendt's friend and colleague at The New School, pointed out in 1966: "what is itself mortal cannot be the vehicle of immortality" ${ }^{80}$ The Human Condition similarly concludes that the world "would lose all its reality" if one knew that it will end soon after one's own death. ${ }^{81}$ The 'knowing' here is of course subjective and applies equally to the eschatological Christian and the climate scientist. Today, due

\footnotetext{
78 Arendt, The Human Condition, 21; Peg Birmingham, 'Worldly Immortality in an Age of Superfluity: Arendt's The Human Condition,” Arendt Studies 2 (2018): 25-35; Patchen Markell, “Anonymous Glory,” European Journal of Political Theory 16 , no. 1 (2017): 77-99.

79 Arendt, Essays in Understanding, 421-422.

${ }^{80}$ Hans Jonas, The Phenomenon of Life. Towards a Philosophical Biology (Chicago: University of Chicago Press, 1966$), 266$.

${ }^{81}$ Arendt, The Human Condition, 120.
} 
to the catastrophic scenarios ahead, doubts and fears regarding the continuity of civilization, this world as we know it are prominent, especially for the younger generations. For us too, it seems that the future

'is 'like a time-bomb buried, but ticking away, in the present'. To the often-heard question Who are they, this new generation? one is tempted to answer, Those who hear the ticking. And to the other question, Who are they who utterly deny them? the answer may well be, Those who do not know, or refuse to face, things as they really are." ${ }^{n 2}$

Deprived of immortality, political action needs other animating principles. Here, I think Arendt's passing reflections on the importance (in exceptional circumstances) of "a fundamental gratitude for the few elementary things that indeed are invariably given to us, such as life itself' is worth reviving. ${ }^{83}$ We might also need, as she later envisaged, a new, geocentric worldview focused on the Earth as the home for mortal human beings, and grounded in aesthetic and political appreciation of the Earth's appearances, the phenomenal beauty of a planet radiating with a diversity of life-forms. The threat to the plurality of appearances should give rise to a worry, a mode of caring, for the world and the Earth instead of succumbing to optimism or despair. ${ }^{84}$ Our main concern, however, should lie with the restructuring of our collective existence. 'Facing things as they really are' requires finding new ways of cultivating facts as the shared infrastructure in the context of which political disagreements are enacted. But pretending they are political programs - making the ecological catastrophe into a technocratic problem-solving feast - is bound to foster a denialist backslash. Once the facts are on the table, the question remains: what are we to do in response to the ticking?

\footnotetext{
${ }^{82}$ Hannah Arendt, Crises of the Republic (New York: Houghton Mifflin Harcourt, 1972), 119-120.

${ }^{83}$ Hannah Arendt, Thinking without a Banister, 418; Arendt, The Origins of Totalitarianism, 435-438.

${ }^{84} \mathrm{It}$ is worth noting that worry and hope, instead of fear, are the emotions capable of motivating a sustained engagement and attentive processing of information in the context of climate change politics. Nicholas Smith and Anthony Leiserowitz, “The Role of Emotion in Global Warming Policy Support and Opposition,” Risk Analysis 34, no. 5 (2014): 937-48.
} 
The answer does not lie exclusively in 'immaterial' values of public freedom, although such conclusion might easily present itself from an Arendtian perspective. At the epicenter of a politics based on a geocentric appreciation of life as it has been given lays a public concern for reorganizing our modes of laboring. In the end, it comes down to reconfiguring, through politics, the relationship between the two oikos-derived words: economy and ecology. While modernity has tended to organize its politics according to the demands of labor and economic growth, we will need to find new ways of organizing labor according to the demands of sustainability-oriented politics. Work and labor, Arendt helps us see, can be more than functions of economic growth: they can be sources of stability, meaning, and joy in our lives. How to organize labor justly, while providing necessities for everybody, is a political question that needs to be addressed in the upcoming years. Luckily, despite the massive scale of required changes, we are not in a hopeless situation. Ours is not a choice between a major popular uprising or continuing on the road to disaster with the powers that be. This is a false, simplistic, and dangerous way of presenting our alternatives. The new political beginnings never occur ab ovo. This means that there are always initiatives to which we can respond - ideas, experiments, policies that can be picked up and amplified. What is required, in any case, is something more than moral or factual preaching - new ways of world-building in the mode of cultivating the Earth rather than imagining ourselves as its masters or entertaining dreams of escaping. Fortunately, although we are forced to witness the piling up of debris, we are not Klee's angel made famous by Walter Benjamin, helplessly blown by the wind of progress towards our demise. We have not lost the capacity to change the world. The time for action has not passed for good. 